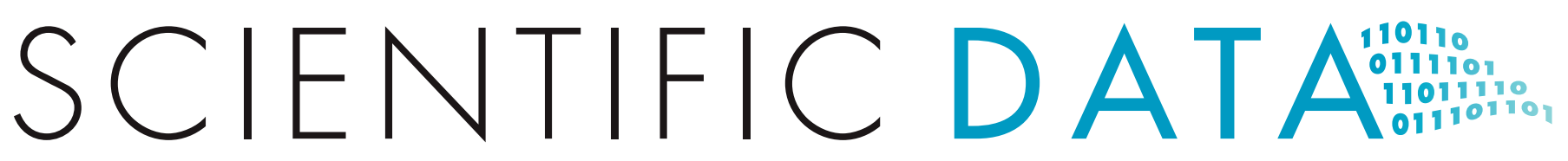

\title{
Corrigendum: The contemporary distribution of Trypanosoma cruzi infection in humans, alternative hosts and vectors
}

Annie J. Browne, Carlos A. Guerra, Renato Vieira Alves, Veruska Maia da Costa, Anne L. Wilson, David M. Pigott, Simon I. Hay, Steve W. Lindsay, Nick Golding \& Catherine L. Moyes

Scientific Data 4:170050 doi:10.1038/sdata.2017.50 (2017); Published 11 April 2017; Updated 30 May 2017

The financial support for this Data Descriptor was not fully acknowledged. The Acknowledgements should have included the following: S.I.H. is funded by a Senior Research Fellowship from the Wellcome Trust [095066].

\begin{abstract}
(c) (i)
Open Access This article is licensed under a Creative Commons Attribution 4.0 International License, which permits use, sharing, adaptation, distribution and reproduction in any medium or format, as long as you give appropriate credit to the original author(s) and the source, provide a link to the Creative Commons license, and indicate if changes were made. The images or other third party material in this article are included in the article's Creative Commons license, unless indicated otherwise in a credit line to the material. If material is not included in the article's Creative Commons license and your intended use is not permitted by statutory regulation or exceeds the permitted use, you will need to obtain permission directly from the copyright holder. To view a copy of this license, visit http://creativecommons. org/licenses/by/4.0/
\end{abstract}

(C) The Author(s) 2017 